\title{
VOCATIONAL INTEREST, COUNSELLING, SOCIO- ECONOMIC STATUS AND AGE AS CORRELATES OF RE-ENTRY OF GIRLS INTO SCHOOL IN EDO STATE
}

\author{
ALIKA, Henrietta Ijeoma PhD \\ Lecturer, \\ Dept of Educational Psychology and Curriculum Studies \\ Faculty of Education, University of Benin, Benin City \\ email: henriettaalika@yahoo.co.uk
}

and

\section{EGBOCHUKU, Elizabeth Omotunde PhD}

Associate Professor,

Dept of Educational Psychology and Curriculum Studies

Faculty of Education, University of Benin, Benin City.

email: mamandidi@yahoo.co.uk

\begin{abstract}
The aim of the study was to investigate the relationship between vocational interest, counselling, socio-economic status and age on re-entry of girls into school in Edo State. One research hypothesis was formulated to guide the study. The design was correlational. Five research instruments were used: they are the Modified Bakare Vocational interest inventory, the instrument on counselling, the instrument on socio-economic status of parents, the instrument on age and the instrument on reasons for re-entry into school by girls. Three continuing education schools were randomly selected for the study. Three hundred and twenty girls who re-enrolled in these schools were used for the study. Data were analyzed using multiple regression analysis method. Results showed that there is a significant relationship between vocational interest, counselling, socioeconomic status on re-entry of girls into school with the exception of age. It is recommended that vocational counsellors should note the age bracket in which girls drop out of schools in order to set in motion some intervention strategies that may reduce the incidence of drop out and enhance the possibility of re-entry into school
\end{abstract}

Key words: Vocational interest, Counselling, Socio-Economic Status, Age, Re-entry, School. 


\section{Introduction}

The National policy on Education has regarded education in Nigeria as an instrument 'per excellence' for effecting national development and it has witnessed the participation by non-governmental organizations, individuals and communities as well as government interventions as exemplified in the introduction of the Universal Basic Education Programme (UBE) aimed at creating equal educational opportunities for all. Despite these lofty plans and objectives some Nigerian girls are still disadvantage in access to education. As a result, all do not register for school, and those who register do not attend school regularly and eventually drop out or learn very little (UNICEF 2004). When they drop out of school, some find it very difficult to re-enter school as a result of some factors subsumed in socio-economic, historical and cultural factors. (Osakwe, Osagie, Madunaga and Usman (1995). With counselling, conducive atmosphere, persuasion and encouragement girls may be persuaded to re-enrol in school and complete their careers. If this is achieved it will go a long way in reducing illiteracy, depression, social mal-adjustment and frustration among girls. Moreover, counselling is capable of redirecting girls towards finding fulfilment in life by going back to school, completing their schooling, thus acquiring basic education that will empower them in the world of work and consequently contribute towards national development. Moreover, the concept of age is attracting more attention from educational psychologists. The girl child is expected to show some level of readiness, and interest in pursuing a vocation with increasing age. Super (1957) reported that reality factors play an increasingly important role in occupational choice with increasing age from early adolescence to adulthood.

\section{The Problem}

A lot of interest has been shown by most African nations in the plight of girls who drop out of school, with Kenya as a case study, where efforts have been made to establish special schools for girls who dropped out of school (Nyambura, 2000). The Federal Government of Nigeria has shown interest also in the plight of children who drop out of school in her Universal Basic Education Programme (1999), which has "catering for the learning needs of the young persons who may have interrupted their education as a result of one reason or the other" as one of her objectives. In fact, people who acknowledge the importance of education have become aware of the implications of education for the Nigerian citizens as elsewhere in the dynamic world. It is this awareness and a desire to find 
out the relationship between vocational interest, counselling, socioeconomic status and age on re-entry of girls into school that has motivated this study. According to a UNICEF (2004) report some 121 million children are out of school for various reasons including poverty and 65 million of them are girls. With the rights of 65 million girls unmet, human resources is wasted and urgent steps need to be taken to ensure that they go back to school, complete their schooling and contribute towards national development. Consequently, this study will attempt to find out the relationship between vocational interest, counselling, socioeconomic status and age on re-entry of girls into school in Edo Sate.

\section{Hypothesis}

There is no significant relationship between vocational interest, counselling, socio-economic status and age on re-entry of girls into school in Edo State.

\section{Method of Study}

The study was correlational. It investigated the extent of relationship between the independent variables and the dependent variable. The survey method was adopted for this study. The population of the study comprises all girls who dropped out of school and re-enrolled. Five research instruments were used: they are the modified Bakare vocational interest inventory, the instrument on counselling, the instrument on socio-economic status of parents, the instrument on age and the instrument on reasons for re-entry into school by girls. Three institutes of continuing education were randomly selected for the study, from the five institutes in the state. Three hundred and twenty girls who enrolled in these schools made up the sample size. The average age of females were $($ mean $=21$ years and a standard deviation of S.D. $=4.73)$.

\section{Results}

Data were analysed using multiple regression analysis. The alpha level of significance was set at 0.05 .

Table 1 reveals that the multiple $\mathrm{R}$ for this model was .607. The joint impact of the independent variables accounted for $35 \%$ (i.e. $R$ (adj. .359) variable in re-entry of girls into school. The beta weight for vocational interest was .187, counselling .178, socio-economic status -9.951 while age was -.165. In order to show the significance of the predictive power of each independent variable, their regression coefficients were computed using the student t-statistics. These variables were tested at 
0.05 level of confidence. The $\mathrm{t}$ values are as follows: vocational interest 5.617, counselling 3.095, socio-economic status -7.874, Age -.289. This shows that the independent variables had significant relationship with reentry of girls into school except that of age, though socio-economic status was negatively significant. It should be noted that vocational interest, counselling and socio-economic status are good predictors of re-entry of girls into school with an $\mathrm{F}$ value $=39.136$. The regression model for this function is re-entry of girls $21.522+$ Vocational interest $+0.187+$ counselling 0.178, + socio-economic status -9.951 and Age -.165. Socioeconomic status was the highest contributor to the variation, followed by vocational interest, and counselling.

Table 1: Regression analysis of vocational interest, counselling, socioeconomic status and age on re-entry of girls into school in Edo State.

\begin{tabular}{|c|c|c|c|c|c|}
\hline \multicolumn{6}{|l|}{$\begin{array}{l}\text { Multiple R .607 } \\
\text { R Square .369 } \\
\text { Adjusted r square } .359 \\
\text { Standard Error } 9.1966\end{array}$} \\
\hline & ss & df & ms & $\mathbf{F}$ & Sig \\
\hline Regression & 13240.090 & 4 & 3310.023 & 39.136 & .000 \\
\hline Residual & 22666.752 & 268 & 84.577 & & \\
\hline \begin{tabular}{|l|} 
Total \\
\end{tabular} & 35906.842 & 272 & & & \\
\hline \multicolumn{6}{|c|}{ Parameter estimates } \\
\hline & B & Std error & Beta & $\mathbf{t}$ & Sig \\
\hline Vocational interest & .187 & .033 & .300 & 5.617 & .000 \\
\hline Counselling & .178 & .058 & .159 & 3.095 & .002 \\
\hline Socio-economic status & -9.951 & 1.264 & -.415 & -7.874 & .000 \\
\hline Age & -.165 & .571 & -.015 & -.289 & .773 \\
\hline Constant & 21.522 & 4.894 & & & .000 \\
\hline
\end{tabular}

Sig. at $\mathrm{p}<0.05$

The hypothesis which states that there is no significant relationship between vocational interest, counselling, socio-economic status and age on re-entry of girls into school is therefore rejected. It is concluded that there is a significant relationship between vocational interest, counselling and socio-economic status with the exception of age on re-entry of girls into school in Edo State.

\section{Discussion of Results}

Results showed that there is a significant relationship between vocational interest, counselling, and socio-economic status on re-entry of girls into 
school with the exception of age. This could be as a result of the significant role that vocational interest, counselling and socio-economic status play in determining re-entry into school. Age may not really be significant because the three main variables determine whether or not to re-enrol in school irrespective of age. This finding is in agreement with that of $\mathrm{Wu}$-Tien (2000), who reported that a considerable proportion of students chose professional and management vocations and students with higher level of vocational aspiration or interest proceed to prepare themselves for a higher level career. Goldsmith and Archabault (1997) in a study that took into account the effect of student characteristics, initial goals, academic and social integration found that for the women who were still in school, their grade point average and financial status are significantly related to their continued stay in school. Egbochuku and Alika, (2008) reported that there is a significant relationship between socio-economic status and vocational interest on re-entry of girls into school.

The result of the study showed a significant relationship between counselling and re-entry of girls into school. Egbochuku (2000) observed that behaviour is a result of socialization therefore, to effect a change in behaviour, the process of re-learning the social setting (group) requires the assistance of the counsellor. She advocated that one of the skills a counsellor can use to bring about a change is cognitive restructuring. Alika and Egbochuku (2007) reported significant relationship between counselling and re-entry of girls into school. In another study, Alika and Egbochuku (2008) found that there is a significant relationship between counselling, vocational interest and socio-economic status on re-entry of girls into school. Boyd (1997) reported a similar finding using students who were academically dismissed at the end of 1994 spring semester. The treatment group comprised of 133 participants, 98 of whom were subsequently approved for reinstatement, thus buttressing the efficacy of counselling. Uba (1983) asserts that whoever enters a particular occupation is usually influenced by the socio-economic class of parents. Shertzer and Stone (1976) reported that socio-economic status of the family influences the vocational preference of youths. Alika (2008), in a study conducted amongst 320 girls who re-entered school in Edo state, found that counselling, vocational interest and socio-economic status significantly determine re-entry of girls into school.

When the age variable was added to vocational interest, counselling and socio-economic status, in order to determine their collective impact on re-entry of girls into school, it was found that age 
had no impact when it was considered along side the other independent variables. This could be as a result of girls deciding to re-enter school at a convenient time irrespective of age. This finding may be as a result of the crucial role that vocational interest, counselling and socio-economic status play in determining re-entry into school irrespective of the age of the individual. One has to be economically empowered, vocationally motivated and counselled in order to decide whether to go back to school or not. It could also be as a result of the emphasis attached to paper qualification or certification in Nigeria.

\section{Implication for Counselling}

There should be public enlightenment programmes on Radio, Television and the Print media on the multiplier effect and intergenerational benefits derivable in girl child education. Indigent students should be identified by counsellors and non-governmental agencies so as to provide them with some scholarships and financial assistance. Vocational counsellors should organize career days and career games in schools so as to acquaint girls who re-enter school with basic information on the various vocations. Group counselling and cognitive restructuring should be adopted by counsellors in order to bring about a change in the behaviour of girls who re-enter school.

The age bracket in which girls drop out of school and re-enter school should be noted by the school counsellors so as to provide some intervention strategies that could prevent drop out, enhance continued stay in school and completion of their careers. This invariably would ensure optimal development of their potentials.

\section{Conclusion and Recommendations}

This study investigated the relationship between Vocational Interest, Counselling, Socio-economic Status and age on Re-entry of girls into school in Edo State. The conclusion drawn from the study is that vocational interest, counselling and socio-economic status, significantly determine re-entry of girls into schools, with the exception of age which had no impact. In other words, an indication of interest in a vocation, the provision of counselling services and enhancement of parents' socioeconomic status greatly determine re-entry into school by girls.

It is recommended therefore, that vocational counselling should be provided in schools, counselling services should be provided for girls who re-enrolled in schools and for girls who are at risk of dropping out of school with a view to ensuring that they get well adjusted in the school systems. Government and non-governmental agencies should provide 
projects that generate income so as to enhance the socio-economic status of the citizens. The age bracket in which girls drop out and re-enter school should be taken note of, so as to provide some intervention strategies that would ensure that the girl child optimally develops her potentials.

\section{References}

Alika, H. I. \& Egbochuku, E. O. (2007). Counselling as a correlate of Reentry of girls into school in Edo State. Studies in Education. A Journal of the Faculty of Education, Ambrose Alli University, Ekpoma, Nigeria,. 9, (1 \& 2). 107 - 112.

Alika, H. I. (2008). Counselling, Vocational Interest and Socio-economic Status as correlates of Re-entry of Girls into School in Edo State. Edo Journal of Counselling,. 1(1) 102-112.

Bakare, G.C.M (1977). Vocational Interest inventory, Ibadan PsychoEducational Research Publication.

Boyd, V. (1997). A Summer retention programme for students who were academically dismissed and applied for reinstatement. Research Report, No. 13-96. Counselling Centre, Margland University College, Park.

Egbochuku, E. O. (2000). Counsellors as facilitators for the successful implementation of the Universal Basic Education Scheme in Nigeria, in J. A. Aghenta and D. Awanbor, (eds.). The Nigerian Academy of Education Proceedings of the 15th Annual Congress of the Nigerian Academy of Education. Ambik Press Limited, Benin City. 359-370.

Egbochuku, E. O. \& Alika, H. I. (2008). Socio-Economic Status and Vocational Interest as correlates of re-entry of girls into schools in Edo State. Benin Journal of Gender Studies, 1(1) 102-112.

Goldsmith, D. J. \& Archabault, F.X. (1997). Persistence of Adult Women in a Community College Re-entry Programme. Eric Document Reproduction Service. No. ed. 409-958.

Nyabura, K. O. (2000). Curbing drop out. Re-entry Programme for teenage mothers. The case of Kenya. A paper presented at the Regional Ministerial Consultation on closing the gender gap in Education.

Osakwe, G. Madunagu, B. I. Usman, H. \& Osagie, J. (1995). Research findings into the reproductive rights of women in Nigeria. International Rights Research Action Group. 
Shertzer, B. \& Stone, S. (1976). Fundamentals of guidance. Boston Houghton Mufflin C. (3) 3-91.

Super, D. E. (1957). The Psychology of Careers. New York Harper and Row Publishers Inc.

Uba, A. (1983). Theories of Personality. In Uba, A. (Ed) Claerianum Press, Ibadan.

Universal Basic Education for Nigeria (1999). Proceedings of the Education Mini Summit, Zaria. Ahmadu Bello University Press Ltd.

United Nations International Children Educational Fund (2004). The State of the Worlds Children Girls Education and Development. 4, 3435.

Wu-Tien, W. U. (2000). Vocational interest and career maturity of Male High School Students talented in Mathematics and Science. National Science Council Production. 10(3), 137-143. 